\title{
Effect of solar UVR on the production of particulate and dissolved organic carbon from phytoplankton assemblages in the Indian Ocean
}

\author{
Antonio Fuentes-Lema ${ }^{1, *}$, Cristina Sobrino ${ }^{1}$, Natalia González $^{2}$, Marta Estrada ${ }^{3}$, \\ Patrick J. Neale ${ }^{4}$
}

\author{
${ }^{1}$ Department of Ecology and Animal Biology, University of Vigo, 36310 Vigo, Spain \\ ${ }^{2}$ Department of Biology and Geology, Rey Juan Carlos University, 28933 Madrid, Spain \\ ${ }^{3}$ Department of Marine Biology and Oceanography, Institut de Ciències del Mar (CSIC), 08003 Barcelona, Spain \\ ${ }^{4}$ Smithsonian Environmental Research Center, PO Box 28, Edgewater, MD 21037, USA
}

\begin{abstract}
This study shows the effects of solar UVR on the photosynthetic parameters and the production of both particulate and dissolved organic carbon (POC and DOC, respectively) of phytoplankton assemblages from oligotrophic areas of the southeastern Indian Ocean. Samples from the $20 \%$ PAR depth were incubated on deck under different intensities of 2 different light regimes: full solar radiation (PAR+UVR) and excluding UVR (PAR). Phytoplankton production was measured by the ${ }^{14} \mathrm{C}$ method, obtaining size-fractionated POC $(0.2,2$ and $20 \mu \mathrm{m})$, total POC and DOC. POC values were fit to a photosynthesis-irradiance $(P-E)$ model that includes photoinhibition. Phytoplankton populations under PAR+UVR had a $10 \%$ lower maximum photosynthetic rate $\left(P_{\mathrm{s}}^{\mathrm{B}}\right)$ and an $86 \%$ higher sensitivity to inhibition $(\beta)$ than populations incubated under only PAR exposures. For some stations, cells larger than $2 \mu \mathrm{m}$ showed higher $P_{\mathrm{s}}^{\mathrm{B}}$ and photosynthetic efficiency (measured as the $P-E$ slope, $\alpha$ ) than smaller cells, but no significant differences were found for $\beta$. In contrast, DOC production was significantly higher under PAR+UVR than under PAR exposures and did not follow the $P-E$ model used for fitting POC. The analysis of the $P-E$ values for DOC production showed that values remained constant under PAR intensities but increased with increasing irradiance in the presence of UVR. In some cases, inhibition of DOC production at high irradiances was also observed. These results demonstrate the relevance of UVR irradiance as an environmental driver for phytoplanktonic DOC production in oligotrophic waters and reinforce the important role of UVR on the physiology and ecology of tropical plankton.
\end{abstract}

KEY WORDS: Ultraviolet radiation $\cdot$ Phytoplankton $\cdot$ POC $\cdot$ DOC $\cdot P-E$ curve $\cdot$ Photoinhibition $\cdot$ Indian Ocean

\section{INTRODUCTION}

Solar UVR (280 to $400 \mathrm{~nm}$ ) is an environmental factor with a strong influence on the biological and chemical processes of the marine environment due to its high energy per wavelength (Neale 2001, Häder et al. 2011). The scientific and social interests in UV-B ( 280 to $315 \mathrm{~nm}$ ) effects have grown over the last decades due to the enhancement of UV-B reach- ing the earth's surface caused by ozone layer depletion. The decrease in ozone concentration mainly affects high latitudes and was initially caused by the release of anthropogenic compounds, such as chlorofluorocarbons (CFCs), in the stratosphere (Molina \& Rowland 1974, Henderson et al. 1991). Since CFC usage has been limited by the Montreal Protocol (UNEP 2000), a recovery of the ozone layer seems to have started (Ravishankara 2009). However, inter- 
active effects with other global change drivers are also affecting stratospheric dynamics and temperature, delaying the ozone layer recovery (Weatherhead \& Andersen 2006). In the marine ecosystem, the increase in sea surface temperature is expected to result in a more stratified upper mixing layer (Capotondi et al. 2012); as a consequence, phytoplankton will be exposed to higher UVR and PAR.

UV-A (315 to $400 \mathrm{~nm}$ ), which is less powerful (i.e. it has less energy per photon) than UV-B, has sometimes been related to cellular repair processes in aquatic organisms (Mitchell \& Karentz 1993, Helbling et al. 2001, Buma et al. 2006) and even to enhancement of carbon fixation under low light conditions (e.g. cloudy days) (Gao et al. 2007b). However, since it is a large component of solar UV irradiance, UV-A exposure is also responsible for most phytoplankton photoinhibition in natural aquatic ecosystems (Helbling et al. 1992, Villafañe et al. 2004). UVA, together with UV-B, is also responsible for coloured dissolved organic matter (CDOM) photodegradation, a photochemical process which transforms refractory molecules into labile organic matter and nutrients available to bacteria and primary producers (Wetzel et al. 1995, Moran \& Zepp 1997). UV-B, on the other hand, exerts a control over phytoplankton populations because of its harmful effects. UV-B radiation can damage biomolecules that directly absorb light in its wavelength range (i.e. aromatic amino acids and DNA) or indirectly through the formation of intermediary metabolites as reactive oxygen species (reviewed in Vincent \& Neale 2000). As a result, UV radiation induces the formation of pyrimidine dimers in DNA (Buma et al. 1996), affects Photosystem II (Schofield et al. 1995) and compromises phytoplankton membrane permeability (Sobrino et al. 2004), among other effects (Sobrinio et al. 2005b), finally decreasing the photosynthetic efficiency of phytoplankton communities and increasing the mortality of phytoplankton cells (Helbling et al. 1992, Llabrés \& Agustí 2006). Chemical processes related to UVR are especially relevant in coastal waters, where the concentration of CDOM is generally high. In contrast, UVR exerts higher effects on biological processes at low latitudes and open ocean waters, where high solar irradiance (clear skies, low zenith angle) and low CDOM ensures a high penetration of UV-B and UV-A. Higher effects on biological rather than chemical processes are also expected in Antarctic waters due to relatively higher amounts of the shortest wavelengths of UVB during springtime episodes of high ozone depletion. Nevertheless, very few UVR studies show responses from tropical open waters compared to the relatively large number of studies carried out in polar waters. A main difference between the effect of solar UVR on the biological processes from low and high latitudes is that the organisms from the former ecosystems are adapted to high levels of solar radiation and are likely to attain high repair rates, while low light adaptation and slower repair are expected in high-latitude organisms (Buma et al. 2003).

Photosynthesis-irradiance $(P-E)$ curves are a fundamental tool to assess the effects of irradiance on phytoplankton through changes in the photosynthetic parameters estimated from the curves or to infer the productivity of the water column from in situ measured light profiles (Forget et al. 2007, Li et al. 2009). However, most of the published curves, both from in situ incubations and under controlled laboratory conditions, are estimated from incubations carried out in UV opaque materials (e.g. Carmack et al. 2004). Moreover, many studies of global net primary production were based on methods such as satellite remote sensing that need to be calibrated by in situ measurements, which in general only take into account the PAR spectra (Field et al. 1998). This lack of proper methods employing the natural solar spectrum (PAR+UVR) also affects the majority of published estimates of global carbon fluxes. Additionally, the traditional emphasis on the flux of particulate organic carbon (POC) has neglected the direct production of dissolved organic carbon (DOC) by phytoplankton and its contribution to the carbon fluxes (del Giorgio \& Duarte 2002). Furthermore, few studies using $P-E$ curves as a proxy to assess primary production in the water column have taken into account UVR effects over different cell sizes (cf. Gao et al. 2007a) or on the production of both POC and DOC, despite the importance of the latter for the microbial loop. Initial studies of the effects of UV radiation on different phytoplankton sizes hypothesized that small cells should be more sensitive to photoinhibition than large ones due to limited photoprotection over a short optical pathway (Garcia-Pichel 1994). However, later results showed that cell size alone is not a good index of UV radiation sensitivity (Laurion \& Vincent 1998). Regarding primary production, UVR photoinhibition of total primary productivity has been reported to be around 10 to $30 \%$ in coastal waters (Helbling et al. 2003, Li et al. 2009) and between 15 and $27 \%$ in open waters (Helbling et al. 1992, Li et al. 2011). In contrast, there is no clear information about the effects of the environmental drivers, including UVR, on the phytoplanktonic release of DOC. DOC production has been related to passive mechanisms 
due to membrane instability and cell breakdown due to grazing (Strom et al. 1997, Teira et al. 2001). Other studies indicate that there is a link between DOC production and stress conditions, including nutrient limitation, photoinhibition by PAR and UVR and cell death (Sharp 1977, Mague et al. 1980, Carrillo et al. 2002, Agustí \& Duarte 2013). Therefore, DOC production can act as a stress indicator reflecting the degree of uncoupling between photosynthesis and growth (Berman-Frank \& Dubinsky 1999). In an effort to answer some of the abovementioned knowledge gaps, the objective of this study was to assess the effects of solar UVR on the photosynthetic parameters of phytoplankton from different size fractions and the production of POC and DOC in oligotrophic areas of the southeastern Indian Ocean.

\section{MATERIALS AND METHODS}

\section{Experimental design}

Experiments were performed on board the RV 'Hespérides' between 15 February and 13 March 2011 during the $3^{\text {rd }}$ leg (23 stations) of a multidisciplinary oceanographic circumnavigation (Malaspina 2010 project) (Fig. 1A). To study the UVR effects on the photosynthetic parameters and the production of phytoplanktonic POC and DOC, 6 stations were sampled at the eastern part of a transect starting in Capetown $\left(32^{\circ} 54^{\prime} \mathrm{S}, 18^{\circ} 25^{\prime} \mathrm{E}\right)$, South Africa, and ending in Perth $\left(32^{\circ} 03^{\prime} \mathrm{S}, 115^{\circ} 44^{\prime} \mathrm{E}\right)$, Australia (Fig. 1C). Water samples were taken with Niskin bottles attached to a profiling CTD rosette (Sea-bird SBE 19) every day around 10:30 h local time at depths corresponding to the $20 \%$ maximum PAR irradiance (PAR 400 to $700 \mathrm{~nm})$. Average UVR \pm SE at that depth corresponded to the $2.1 \pm 0.8 \%$ of maximum UVR at the surface. This depth usually corresponds to the primary productivity maximum following a typical tropical water column structure (Herbland \& Voituriez 1979). Solar exposures were carried out on deck, in an area without shadows, using incubators holding polymethylmethacrylate cylinders transparent to the full solar radiation spectrum (Plexiglas R XT). Incu- bators were connected to the continuous seawater pumping system of the ship to assure cooling of the samples during the incubation period. To obtain 2 different spectral treatments, one of the incubators was wrapped with a 226 Lee UV cellulose acetate filter, which is transparent to PAR but opaque to UVR (UV-opaque; treatment UVO: $92 \%$ of transmittance $[T]$ at $700 \mathrm{~nm}$ and $50 \% T$ at $400 \mathrm{~nm}$ ), and the other was wrapped with an Ultraphan 295 filter, which is transparent to PAR and UVR (UV-transparent; treatment UVT: $93 \% T$ at $700 \mathrm{~nm}$ and $50 \% T$ at $295 \mathrm{~nm}$ ) (Fig. 2B).

\section{Properties of the water column and estimation of \\ incident radiation}

Physical properties of the water column such as temperature, salinity and mixed layer depth $\left(z_{\mathrm{m}}\right)$ were obtained from the CTD rosette profiles. $z_{\mathrm{m}}$ was
Chl $a$

$\left(\mathrm{mg} \mathrm{m}^{-3}\right)$

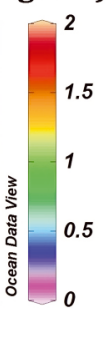

. Black dots correspond to locations of the sampling stations where the UVR
experiments in this study were carried out. (B) Incident total solar radiation $\left(\mathrm{W} \mathrm{m} \mathrm{m}^{-2}\right.$ ) along the transect. (C) Concentration $\left(\mathrm{mg} \mathrm{m}^{-3}\right)$ of chl a from the the sampling locations 

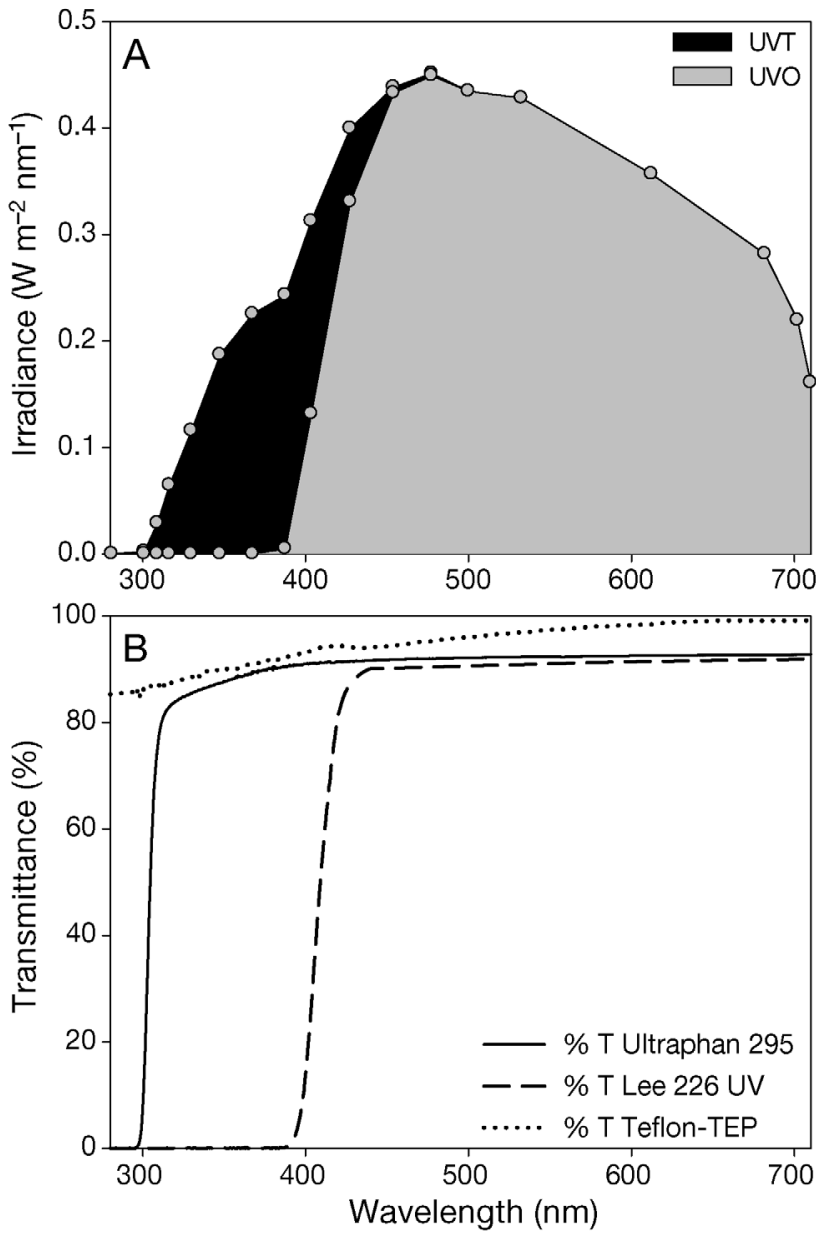

Fig. 2. (A) Spectra of incident solar radiation, $E_{0}\left(\mathrm{~W} \mathrm{~m}^{-2}\right.$ $\mathrm{nm}^{-1}$ ), corresponding to Stn 060, corrected by Teflon bottles and absorbance by the 2 cellulose acetate filters. An Ultraphan 295 was used for the UV-transparent (UVT) treatment (black), and a 226 Lee UV was used for the UV-opaque (UVO) treatment (gray); gray circles correspond to data registered by the Biospherical PRR-800 radiometer. (B) Transmittance spectra $(\% T)$ of solar radiation after passing through the Teflon-transparent exopolymer particle bottles (dotted line) and Ultraphan 295 and 226 Lee UV cellulose acetate filters (solid line and discontinuous line, respectively) used for achieving UVT and UVO treatments, respectively, during deck incubations defined as the depth where water temperature differs from the sub-surface water temperature $(10 \mathrm{~m}$ depth) by more than $1{ }^{\circ} \mathrm{C}$, following the criteria used in the Indian Ocean by Rao et al. (1989). Optical properties of the water column (PAR and UVR irradiance) and extinction coefficients, $K_{\mathrm{d}}$, were obtained at each station from profiles of an underwater multichannel radiometer (Biospherical PRR-800 with detectors at 305, 313, 320, 340, 380, 395, 412, 443, 465, $490,510,555,670,694$ and $710 \mathrm{~nm}$ plus a broad-band PAR sensor). Each profile was performed at local noon by the starboard, fully exposed side of the ship at $10 \mathrm{~m} \mathrm{~min}^{-1}$. Incident solar radiation in surface waters, $E_{\mathrm{o}}(\lambda)$ (Fig. 2A), was calculated using the following equation (Kirk 1983):

$$
E_{z}(\lambda)=E_{\mathrm{o}}(\lambda) \cdot \mathrm{e}^{-k_{\mathrm{d}}(\lambda) \cdot z}
$$

where $E_{z}(\lambda)$ and $k_{\mathrm{d}}(\lambda)$ are the spectral irradiance at depth $z$ and wavelength $\lambda$ and the diffuse attenuation coefficient at wavelength $\lambda$ calculated from the light profile, respectively. Total radiation during incubations was also recorded with a CMP 11 hemispherical pyranometer (Kipp \& Zonen) located at the meteorological station on the highest deck to avoid shadows from the ship (Fig. 1B). Average total irradiance recorded by the pyranometer was used to calculate the average PAR received by the samples during the incubations (Frouin \& Pinker 1995). The values estimated from the pyranometer were validated with a Surface PAR QSR-2200 sensor. Average PAR during the incubations was then related to the area below the spectrum obtained with the multichannel radiometer (between 400 and $700 \mathrm{~nm}$ ), and UVR was calculated as the remaining area between 280 and $400 \mathrm{~nm}$ (Table 1, Fig. 2A). These values were finally corrected by the spectral transmittance of the incubation setup (Plexiglas, Teflon bottles and filters used for each experimental treatment [see below]) to get the final average irradiance reaching the different spectral treatments (Fig. 2A,B).

Table 1. Characteristics of the sampled stations and light conditions during the incubations. $z_{\mathrm{m}}$ : mixed layer depth, $z_{\mathrm{s}}$ : sample depth; chl a: total chlorophyll $a_{i}$ UVR: mean incident ultraviolet radiation during the incubations; PAR: mean incident photosynthetically active radiation during the incubations

\begin{tabular}{|c|c|c|c|c|c|c|c|c|c|}
\hline Stn & $\begin{array}{c}\text { Date } \\
\text { (dd/mm/yyyy) }\end{array}$ & Latitude & Longitude & $\begin{array}{l}Z_{\mathrm{m}} \\
(\mathrm{m})\end{array}$ & $\begin{array}{c}Z_{\mathrm{s}} \\
(\mathrm{m})\end{array}$ & $\begin{array}{c}\text { Temperature } \\
\left({ }^{\circ} \mathrm{C}\right)\end{array}$ & $\begin{array}{c}\mathrm{Chl} \mathrm{a} \\
\left(\mathrm{mg} \mathrm{m}^{-3}\right)\end{array}$ & $\begin{array}{c}\text { UVR } \\
\left(\mathrm{W} \mathrm{m}^{-2}\right)\end{array}$ & $\begin{array}{c}\text { PAR } \\
\left(\mathrm{W} \mathrm{m}^{-2}\right)\end{array}$ \\
\hline 058 & 02/03/2011 & $29^{\circ} 48^{\prime} 04^{\prime \prime} \mathrm{S}$ & $79^{\circ} 37^{\prime} 16^{\prime \prime} \mathrm{E}$ & 51 & 45 & 22.7 & 0.045 & 51 & 493 \\
\hline 060 & 04/03/2011 & $29^{\circ} 44^{\prime} 56^{\prime \prime} \mathrm{S}$ & $86^{\circ} 15^{\prime} 22^{\prime \prime} \mathrm{E}$ & 60 & 58 & 21.4 & 0.049 & 43 & 328 \\
\hline 062 & 06/03/2011 & $29^{\circ} 40^{\prime} 05^{\prime \prime} \mathrm{S}$ & $93^{\circ} 00^{\prime} 15^{\prime \prime} \mathrm{E}$ & 32 & 39 & 21.7 & 0.056 & 48 & 450 \\
\hline 065 & 09/03/2011 & $30^{\circ} 21^{\prime} 58^{\prime \prime} \mathrm{S}$ & $103^{\circ} 35^{\prime} 42^{\prime \prime} \mathrm{E}$ & 53 & 46 & 20.8 & 0.124 & 44 & 370 \\
\hline 066 & 10/03/2011 & $30^{\circ} 48^{\prime} 29^{\prime \prime} \mathrm{S}$ & $107^{\circ} 15^{\prime} 22^{\prime \prime} \mathrm{E}$ & 70 & 32 & 23.04 & 0.159 & 27 & 202 \\
\hline 068 & $12 / 03 / 2011$ & $31^{\circ} 42^{\prime} 00^{\prime \prime} \mathrm{S}$ & $114^{\circ} 28^{\prime} 41^{\prime \prime} \mathrm{E}$ & 38 & 35 & 24.6 & 0.117 & 28 & 232 \\
\hline
\end{tabular}




\section{Determination of POC, DOC and size-fractionated POC production}

Primary production was calculated following the ${ }^{14} \mathrm{C}$ method developed by Steeman-Nielsen (1952) by which inorganic radioactive carbon is assimilated into the particulate fraction (i.e. molecules or cellular structures larger than $0.2 \mu \mathrm{m}$ ) or remains as free organics suspended in the dissolved fraction (molecules smaller than $0.2 \mu \mathrm{m}$ ).

Twenty-two UVR-transparent Teflon-FEP bottles of $33 \mathrm{ml}$ capacity were filled with sample water from the Niskin bottle; 200 to $300 \mu \mathrm{l}$ of $\mathrm{H}^{14} \mathrm{CO}_{3}$ stock solution $\left(100 \mu \mathrm{Ci} \mathrm{ml}{ }^{-1}\right)$ was added to each of the 22 bottles. Ten bottles were wrapped with a set of neutral density screens, made with different kinds of black fabric and mesh, and 1 bottle was left without a screen to receive the maximum irradiance. This was performed in duplicate to obtain a set of 11 different irradiances for each of the 2 spectral treatments, UVO and UVT. The neutral density screens act as filters that allow the transmission of different light intensities without modifications of the spectrum. The light transmission for each neutral density screen was previously determined in the lab by a spectrophotometer (Beckman DU 640), resulting in an irradiance gradient of $0,2,7,14,26,36,47,60,74$ and $85 \% \mathrm{~T}$. After ${ }^{14} \mathrm{C}$ addition, each set of bottles was immediately placed on a UVR-transparent Plexiglas tray designed to keep bottles in a fixed position inside the incubators and transported to the deck under dark conditions for incubation. Incubations were performed around midday under variable weather conditions (see light conditions in Table 1) and lasted $200 \mathrm{~min}$ in all stations except Stn 058, where due to logistical problems the incubation period lasted $130 \mathrm{~min}$.

Sample processing was carried out just after the end of the incubations. Samples were transported to the lab covered by an opaque black bag and immediately filtered under dark conditions. To obtain sizefractionated POC, $25 \mathrm{ml}$ of each sample was filtered through a filtration column connected to a vacuum pump at low pressure $(50 \mathrm{~mm} \mathrm{Hg})$ and filled with $47 \mathrm{~mm}$ diameter polycarbonate (PC) filters of 2 and $0.2 \mu \mathrm{m}$ pore size in most of the cases $(\mathrm{n}=5$, see 'Results') and 20, 2 and $0.2 \mu \mathrm{m}$ pore size in the station closest to the coast, where the largest cell sizes were expected. Filtration for DOC assessment was performed concomitantly with the size-fractionated POC filtration using a different filtration system. Samples $(5 \mathrm{ml})$ were filtered through $25 \mathrm{~mm}$ diameter, $0.2 \mu \mathrm{m}$ pore size PC filters using a 10-place filter manifold connected to a vacuum pump under very low pressure $(50 \mathrm{~mm} \mathrm{Hg})$ to avoid structural cell damage. POC (total POC in contrast to size-fractionated POC) was retained in the filter, while DOC was collected in scintillation vials placed directly under the filter. The percentage of DOC extracellular release (PER) was calculated as the ratio of DOC divided by DOC $+\mathrm{POC}$ productivity. For decontamination of radioactive inorganic carbon, filters were exposed to acid fumes $(\mathrm{HCl} 50 \%$ ), or $200 \mu \mathrm{l}$ of $\mathrm{HCl} 50 \%$ was added to the filtrates and shaken overnight. After decontamination, a scintillation cocktail was added, and the radioactivity of each sample was measured in a Wallac WinSpectral 1414 scintillation counter on board. Triplicate $10 \mu \mathrm{l} \mathrm{H}{ }^{14} \mathrm{CO}_{3}$ stock solutions were inoculated to filtered seawater $(0.2 \mu \mathrm{m})$ plus Carbosorb to obtain the total counts. To measure size-fractionated chl $a$ concentrations, $500 \mathrm{ml}$ of sample was filtered following a similar protocol and using the same filter types as those employed for size-fractionated POC determination (Estrada 2012). Total chl a values used to determine chl a-normalized photosynthesis in the total POC were obtained from the sum of the different fractionated chlorophyll concentrations. Total chl a for descriptive purposes (i.e. Fig. 1C [whole transect] and Table 1 [stations for this study]) was determined from plankton samples collected on GF/F filters and resulted in approximately $24 \%$ higher values than those observed from the sum of the fractions obtained with PC filters. All filters were extracted in $90 \%$ acetone at $4^{\circ} \mathrm{C}$ overnight and analysed on board by fluorometry. Dissolved inorganic carbon values come from the GLODAP database (Key et al. 2004). Water samples for micro- and nanophytoplankton examination were taken from the Niskin bottles at the depth of $20 \%$ PAR and fixed with $0.4 \%$ hexamine-buffered formaldehyde. Phytoplankton analysis was performed by the inverted microscope technique after sedimentation of $100 \mathrm{ml}$ of water in composite chambers for $48 \mathrm{~h}$. Concurrently, the abundance of autotrophic picoplankton was also determined. Small volumes of water sample (>3 ml) were filtered with a $20 \mu \mathrm{m}$ mesh and fixed with $1 \%$ paraformaldehyde $+0.05 \%$ glutaraldehyde until further analysis. Flow cytometry was carried out on board using a FACScalibur flow cytometer (Beckton-Dickinson) (Lubián 2012).

\section{$P-E$ curve analysis}

For each station and spectral treatment, photosynthesis normalized to $\mathrm{chl}$ a $\left(P^{\mathrm{B}}\right)$ versus irradiance $(E)$ 
was described by the following equation modified from Sobrino et al. (2005a) (also known as the threshold, T, model):

$$
P^{\mathrm{B}}=P_{\mathrm{s}}^{\mathrm{B}} \cdot \tanh \left(\alpha \cdot E / P_{\mathrm{s}}{ }^{\mathrm{B}}\right) \cdot \min (1,1 / E \cdot \beta)
$$

where $P_{\mathrm{s}}^{\mathrm{B}}\left(\mathrm{mg} \mathrm{C} \mathrm{mg} \mathrm{chl} a^{-1} \mathrm{~h}^{-1}\right)$ represents the maximum photosynthetic production in the absence of inhibition, $\alpha\left(\mathrm{mg} \mathrm{C} \mathrm{mg} \mathrm{chl} a^{-1} \mathrm{~h}^{-1}\left(\mathrm{Wm}^{-2}\right)^{-1}\right)$ is the initial slope of the curve and indicates the photosynthetic efficiency, $E$ is a given PAR irradiance and $\beta$ (mg C mg chl $a^{-1} \mathrm{~h}^{-1}\left(\mathrm{~W} \mathrm{~m}^{-2}\right)^{-1}$ ) represents the sensitivity to photoinhibition. Additional informative parameters are the onset of light saturation $\left(E_{\mathrm{s}}\right)$, obtained by dividing $P_{\mathrm{s}}{ }^{\mathrm{B}}$ and $\alpha_{i} P_{\mathrm{m}}{ }^{\mathrm{B}}$, the maximum realized rate of photosynthesis $\left(P^{\mathrm{B}}\right)$; and $E_{\mathrm{T}}$, the threshold for the onset of inhibition, $E_{\mathrm{T}}=1 / \beta$.

Curve fitting was performed in 2 stages. Initially, photosynthetic parameters were estimated using Eq. (2) separately for each experiment and each treatment. Following this analysis, joint fits were performed to estimate overall factors for UVT versus UVO. The motivation for this is explained in the 'Results' section. Eq. (2) was fit simultaneously to data from all stations to estimate a set of $P_{\mathrm{s}}{ }^{\mathrm{B}}, \alpha$ and $\beta$ for each station's UVO results, plus factors applicable over all stations for UV treatment effects on $P_{\mathrm{s}}^{\mathrm{B}}$ and $\beta$, i.e. for any given station, $P_{\mathrm{s}}^{\mathrm{B}}{ }_{(\mathrm{UVT})}=1+F_{\mathrm{a}} P_{\mathrm{s}}{ }_{(\mathrm{UVO})}^{\mathrm{B}}$ and $\beta_{(\mathrm{UVT})}=1+F_{\mathrm{b}} \beta_{(\mathrm{UVO})}$, where $F_{\mathrm{a}}$ and $F_{\mathrm{b}}$ are the treatment factors for $P_{\mathrm{s}}^{\mathrm{B}}$ and $\beta$, respectively. Thus, the number of parameters in a joint fit were $3 n+2$, where $n$ is the number of stations in the fit. To characterize the fit of the joint model to individual stations, a squared correlation coefficient, $\mathrm{r}^{2}$, was calculated between the observed and predicted UVO and UVT data for that station.

\section{Statistical analysis}

To assess significant differences between spectral treatments, several statistical analyses were done. When normality and homoscedasticity principles were properly followed, a $t$-test for paired samples was carried out. When these principles were not followed, a non-parametric repeated-measures ANOVA (RMANOVA) and a Dunn's multiple comparison post test were chosen. A 95\% confidence level was established, and all analyses were carried out employing the statistical programme GraphPad InStat TM v2.04a+ and MATLAB 7.0.1 software.

\section{RESULTS}

Phytoplankton communities were studied along a longitudinal transect that involved a broad geographic area in the southeastern Indian Ocean (Table 1, Fig. 1A). The main feature of the chl a distribution was a subsurface chl a maximum at depths ranging from $40 \mathrm{~m}$ near the western coast of Africa, to $150 \mathrm{~m}$ in the middle of the Indian South Subtropical Gyre (Fig. 1C). Chl a concentrations at the $20 \%$ light level of the 6 experimental stations ranged from 0.045-0.056 $\mu \mathrm{g} \mathrm{l^{-1 }}$ at Stns 058, 060 and 062 (gyral stations), located at the eastern border of the Indian South Subtropical Gyre, to $0.117-0.159 \mu \mathrm{g}$ $\mathrm{l}^{-1}$ at Stns 065, 066 and 068 (coastal stations), closer to the Australian coast (Table 1). The picophytoplankton composition was fairly similar at the 6 stations and comprised mainly Prochlorococcus sp. and Synechococcus sp., with Prochlorococcus sp. as the most abundant (observed mean \pm SD values along the whole transect were $96.6 \pm 6.0 \times 10^{3}$ and $8.1 \pm 1.5 \times$ $10^{3} \mathrm{cells} \mathrm{ml}^{-1}$, respectively [M. Llabrés pers. comm.]). The contribution of picophytoplankton to total chl a ranged from $54-57 \%$ at the gyral stations to $60-61 \%$ at Stns 066 and 068; the proportion of chl $a$ in the 2-0.2 $\mu \mathrm{m}$ fraction of Stn 065 was exceptionally high and may be explained by small pennate diatoms (which were particularly abundant at this station and could have widths of about $1 \mu \mathrm{m}$ ) passing through the $2 \mu \mathrm{m}$ filter. The nano- and microphytoplankton groups, which comprised mainly dinoflagellates, flagellates and coccolithophores, also presented comparable average concentrations for the gyral and coastal stations; mean \pm SD values for each group of stations were, respectively, $2200 \pm 1200$ and $2900 \pm$

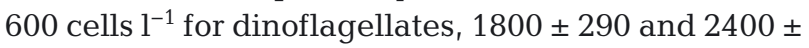

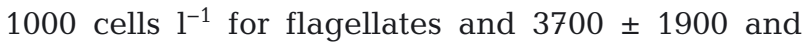

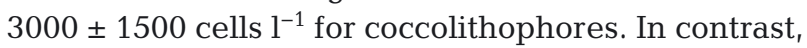
average population densities of diatoms were about 6

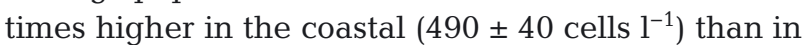
the gyral stations $\left(90 \pm 30\right.$ cells $\left.1^{-1}\right)$. The most abundant dinoflagellates were small gymnodinioids: Gyrodinium spp., Oxytoxum spp., Scrippsiella spp. and Torodinium robustum. The coccolithophores included Discosphaera tubifera, Syracosphaera cf. pulchra (mainly heterococcolithophore stages) and Umbellosphaera irregularis. Diatoms were principally represented by small and large pennates (up to

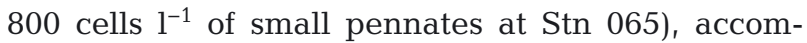
panied in the eastern stations by Leptocylindrus mediterraneus (with its Rhizomonas setigera epibiont). Mean PAR and UVR received during incubations ranged between 493 and $51 \mathrm{~W} \mathrm{~m}^{-2}$, respec- 
tively, on a sunny day (Stn 058) to between 202 and $27 \mathrm{~W} \mathrm{~m}^{-2}$, respectively, on a cloudy day (Stn 066) (Table 1). Temperature values at sampling depth were within a narrow range of $\pm 3.8^{\circ} \mathrm{C}$, and sample depth ranged between 58 and $32 \mathrm{~m}$. All samples, except Stn 062, were taken above the mixed layer depth (Table 1).

Initially, $P-E$ curve fits were performed for individual stations and treatments (results not shown). These fits were performed with limited degrees of freedom $(\mathrm{df}=\mathrm{n}-3)$, a maximum of 8 to a minimum of 5 when outlier points were omitted. This led to large uncertainties in $P_{\mathrm{s}}^{\mathrm{B}}$. Therefore, we instead focused our initial analysis on $P_{\mathrm{m}}{ }^{\mathrm{B}}$, the maximum realized rate of photosynthesis $\left(P^{\mathrm{B}}\right)$ for individual stations/treatments. It was observed that the maximum realized rate of POC incorporation $\left(P_{\mathrm{m}}{ }^{\mathrm{B}}\right)$ and the onset of inhibition $\left(E_{\mathrm{T}}\right)$ were consistently higher for the UVO treatment versus the UVT treatment (cf. Fig. 3). There was no evidence of differences in the initial slope of the $P-E$ curve $(\alpha)$ between UVO and UVT treatments. Thus, joint fits were performed to determine $\alpha, P_{\mathrm{s}}^{\mathrm{B}}$ and $\beta$ in the UVO treatment at each station plus overall factors for the effect of UVT treatment on the parameters controlling $P^{\mathrm{B}}$ at saturated and inhibiting irradiance, $P_{\mathrm{s}}^{\mathrm{B}}$ and $\beta$. The goal of these analyses was to define general factors for UV effects on $P_{\mathrm{s}}{ }^{\mathrm{B}}\left(F_{\mathrm{a}}\right)$ and $\beta\left(F_{\mathrm{b}}\right)$ applicable over all stations for each type of experiment (total and fractions). These joint estimates generally resulted in good fits, with $\mathrm{R}^{2}$ ranging from 0.81 to 0.90 (Table 2). Also, this substantially improved the accuracy of the estimated $P_{\mathrm{s}}{ }^{\mathrm{B}}$. For total
Fig. 3. Photosynthesis-irradiance $(P-E)$ curves of total particulate organic carbon incorporation of all stations estimated using a joint fit of all stations to the Sobrino et al. (2005a) T model. Open triangles and discontinuous lines represent observed and estimated values, respectively, in the UV-opaque (UVO) treatment. Solid dots and solid lines represent observed and estimated values, respectively, in the UV-transparent (UVT) treatment. The lower and upper $x$-axes represent PAR ( $\mu \mathrm{mol}$ photons $\mathrm{m}^{-2}$ $\mathrm{s}^{-1}$ ) and the equivalent PAR+UVR $\left(\mathrm{W} \mathrm{m}^{-2}\right)$ for each station, respectively. Note that irradiance scaling is different among stations to improve clarity. $P^{\mathrm{B}}$ : photosythesis normalized to chl a
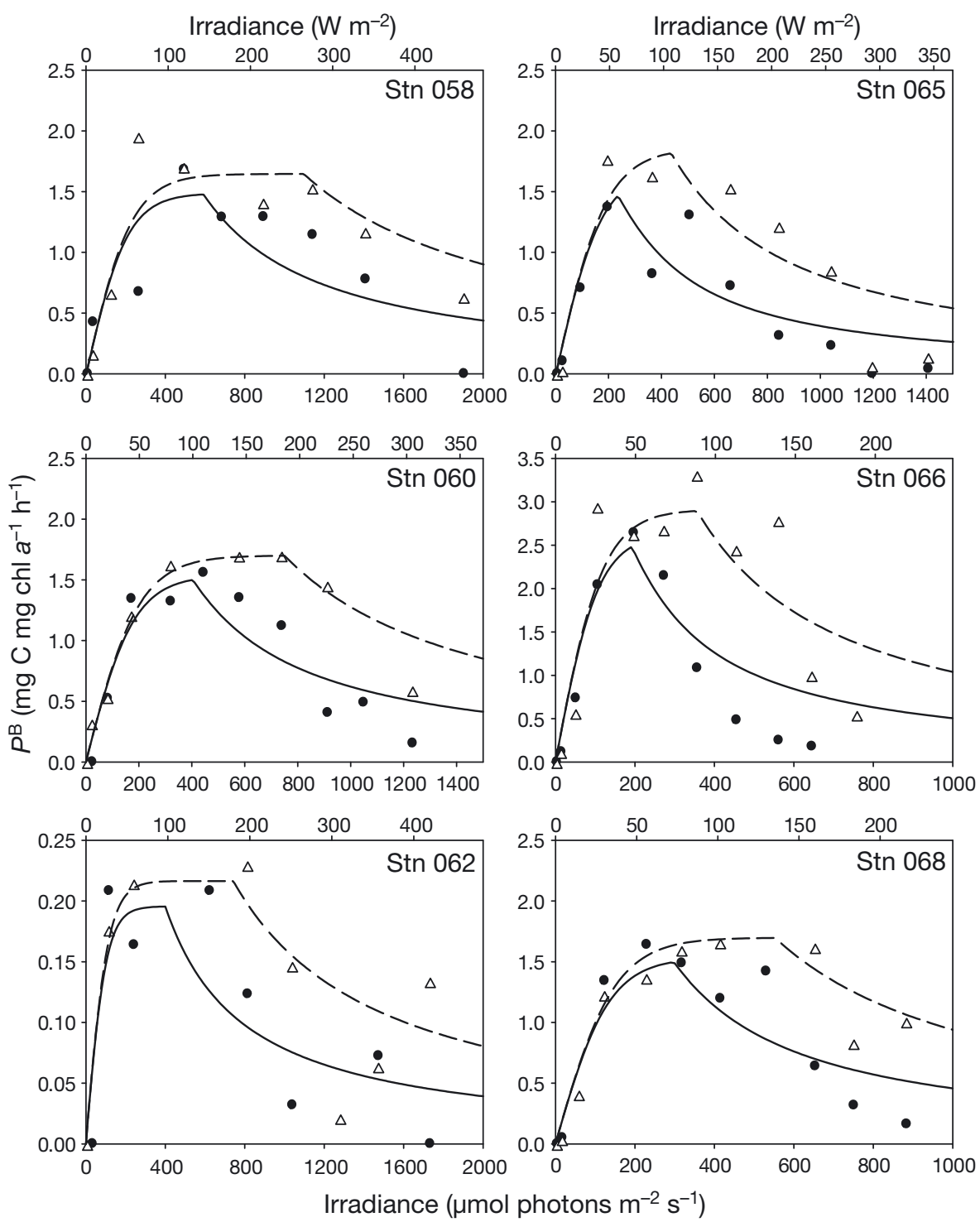
Table 2. Treatment factors for photosynthesis-irradiance $(P-E)$ parameters $P_{\mathrm{s}}^{\mathrm{B}}\left(F_{\mathrm{a}}\right)$ and $\beta\left(F_{\mathrm{b}}\right)$. Overall percent difference $( \pm \mathrm{SE})$ of UV-transparent (UVT) from UV-opaque (UVO) (negative $=$ UVT $<$ UVO) for total and fractionated particulate organic carbon $P-E$ experiments as estimated from joint $P-E$ fits for all experiments in each category. Coefficient of determination $\left(\mathrm{R}^{2}\right)$ and degrees of freedom (df) are given for each joint fit. $P_{\mathrm{s}}^{\mathrm{B}}$ : maximum photosynthetic rate; $\beta$ : sensitivity to inhibition; $F_{\mathrm{a}}$ and $F_{\mathrm{b}}$ are the treatment factors for $P_{\mathrm{s}}^{\mathrm{B}}$ and $\beta$, respectively; nd: not determined

\begin{tabular}{|lcrrr|}
\hline Size fraction $(\mu \mathrm{m})$ & $P_{s}^{\mathrm{B}}\left(F_{\mathrm{a}}\right)(\%)$ & $\beta\left(F_{\mathrm{b}}\right)(\%)$ & $\mathrm{R}^{2}$ & $\mathrm{df}$ \\
\hline Total & $-10 \pm 13$ & $86 \pm 29$ & 0.86 & 94 \\
$>20$ & $\mathrm{nd}$ & $110 \pm 35$ & 0.90 & 14 \\
$20-2$ & $7.2 \pm 16.5$ & $53 \pm 26$ & 0.86 & 81 \\
$2-0.2$ & $-29 \pm 9$ & $31 \pm 21$ & 0.81 & 94 \\
\hline
\end{tabular}

POC, the UVT treatment was associated with an $86 \pm$ $29 \%$ increase in $\beta$ (Table $2, F_{\mathrm{b}}$ ). The UVT effect on $P_{\mathrm{s}}^{\mathrm{B}}$ $\left(F_{a}\right)$ was a decrease of $10 \%$, but this was not significantly different from zero $(\mathrm{p}>0.05, \mathrm{df}=94)$. Within the fractionated POC measurements, there was a significant increase in $\beta$ in the UVT treatment for the $>2 \mu \mathrm{m}$ fraction and for the $>20 \mu \mathrm{m}$ fraction at Stn 068 . The 0.2 to $2 \mu \mathrm{m}$ (picoplanktonic) fraction had both a significant decrease in $P_{\mathrm{s}}^{\mathrm{B}}$ and an increase in $\beta$ under the UVT treatment.

The fits for the individual stations of fractionated POC measurements showed squared correlation coefficients, $R^{2}>0.64$, except for Stn 062 and the smallest fraction of Stn 060 (Table 3). These latter stations all had very low $P^{\mathrm{B}}$ values. Similar $\mathrm{R}^{2}$ values of fractionated POC were found among size class fractions. Slightly better $\mathrm{R}^{2}$ values were obtained fitting the $P-E$ curve to total POC compared to fractionated values $\left(\mathrm{R}^{2}=0.83 \pm 0.07, \mathrm{n}=6\right.$, Table 4$)$.

Values estimated from the $P-E$ curves showed that maximum productivity normalized to $\mathrm{chl} a\left(P_{\mathrm{s}}{ }^{\mathrm{B}}\right)$ did not follow a longitudinal trend (Tables $3 \& 4$ ). The highest productivity in the total POC was found at Stn 066 (817 km from the coast), with $2.6 \mathrm{mg} \mathrm{C} \mathrm{mg}$ chl $a^{-1} \mathrm{~h}^{-1}$ under full solar spectra (UVT treatment) and $2.9 \mathrm{mg} \mathrm{C} \mathrm{mg} \mathrm{chl} \mathrm{a}^{-1} \mathrm{~h}^{-1}$ under PAR spectra (UVO treatment) (Table 4). Both $P_{\mathrm{s}}^{\mathrm{B}}$ and $\alpha$ were significantly higher at Stn 066 compared to other stations (t-test, $\mathrm{p}<0.001)$. The lowest values were observed in an oceanic station (Stn 062), with 0.20 and $0.22 \mathrm{mg} \mathrm{C} \mathrm{mg}$ chl $a^{-1} \mathrm{~h}^{-1}$ under UVT and UVO treatments, respectively (Table 4). Regarding fractionated POC, the lowest $P_{\mathrm{m}}{ }^{\mathrm{B}}$ values were also found at Stn 062 and always in the smallest cell size fraction (0.2 to $2 \mu \mathrm{m}$ ). For all of the stations, $P_{\mathrm{s}}^{\mathrm{B}}$ was 2 times higher or more in phytoplankton cells larger than $2 \mu \mathrm{m}$ than in cells smaller than $2 \mu \mathrm{m}$. At Stns 065 and 068, the ratio increased up to 12 times (Table 3). Also for these 2 stations, cells $>2 \mu \mathrm{m}$ were also significantly more photosynthetically efficient (higher $\alpha, t$-test $\mathrm{p}<$ 0.001 ) than the smaller size fraction; the $\alpha$ parameter was not significantly different between fractions at other stations. Significant differences were not found between the different size fractions in the $\beta$ of the UVO treatment, i.e. sensitivity to photoinhibition by PAR.

Table 3. Photosynthetic parameters estimated from $P-E$ curves of fractionated particulate organic carbon based on joint fits of UV-opaque (UVO) and UV-transparent (UVT) curves from all stations. The UVT values for $P_{\mathrm{s}}^{\mathrm{B}}$ and $\beta$ reflect application of the corresponding UV treatment factor $\left(F_{\mathrm{a}}\right.$ and $F_{\mathrm{b}}$, respectively) for the given size fraction (cf. Table 2). Chl a: fractionated chl a concentration $\left(\mathrm{mg} \mathrm{m}^{-3}\right) ; \alpha \cdot 10^{3}$ : photosynthetic efficiency [mg C mg chl $\mathrm{a}^{-1} \mathrm{~h}^{-1}$ ( $\mu \mathrm{mol}$ photon $\left.\mathrm{m}^{-2} \mathrm{~s}^{-1}\right)^{-1}$ ]; $E_{\mathrm{s}}$ : saturation irradiance ( $\mu \mathrm{mol}$ photon $\left.\mathrm{m}^{-2} \mathrm{~s}^{-1}\right) ; P_{\mathrm{s}}^{\mathrm{B}}$ : normalized maximum productivity $\left(\mathrm{mg} \mathrm{C} \mathrm{mg} \mathrm{chl} \mathrm{a}^{-1} \mathrm{~h}^{-1}\right) ; \beta \cdot 10^{3}$ : photoinhibition coefficient [mg C mg chl $\mathrm{a}^{-1} \mathrm{~h}^{-1}$ ( $\mu \mathrm{mol}$ photon $\left.\mathrm{m}^{-2} \mathrm{~s}^{-1}\right)^{-1}$ ]; $\mathrm{R}^{2}$ : squared correlation index (dimensionless)

\begin{tabular}{|c|c|c|c|c|c|c|c|}
\hline Stn & $\begin{array}{l}\text { Size fraction } \\
(\mu \mathrm{m})\end{array}$ & Chl a & $\alpha \cdot 10^{3} \pm \mathrm{SE}$ & $E_{\mathrm{s}}$ & $P_{\mathrm{s}}^{\mathrm{B}}[\mathrm{UVT} \mathrm{UVO}] \pm \mathrm{SE}$ & $\beta \cdot 10^{3}[\mathrm{UVT} \mathrm{UVO}] \pm \mathrm{SE}$ & $\mathrm{R}^{2}$ \\
\hline 058 & $\begin{array}{c}>2 \\
2-0.2\end{array}$ & $\begin{array}{l}0.013 \\
0.019\end{array}$ & $\begin{array}{r}4.9 \pm 6.3 \\
13.0 \pm 5.7\end{array}$ & $\begin{array}{r}334 \\
83\end{array}$ & $\begin{array}{l}{\left[\begin{array}{ll}1.7 & 1.6\end{array}\right] \pm 1.0} \\
{\left[\begin{array}{ll}0.8 & 1.1\end{array}\right] \pm 0.1}\end{array}$ & $\begin{array}{l}{\left[\begin{array}{ll}1.2 & 0.8\end{array}\right] \pm 0.6} \\
{\left[\begin{array}{ll}0.7 & 0.5\end{array}\right] \pm 0.2}\end{array}$ & $\begin{array}{l}0.64 \\
0.71\end{array}$ \\
\hline 060 & $\begin{array}{c}>2 \\
2-0.2\end{array}$ & $\begin{array}{l}0.016 \\
0.022\end{array}$ & $\begin{array}{l}7.6 \pm 5.6 \\
6.3 \pm 2.1\end{array}$ & $\begin{array}{l}331 \\
218\end{array}$ & $\begin{array}{l}{\left[\begin{array}{ll}2.7 & 2.5\end{array}\right] \pm 1.8} \\
{\left[\begin{array}{ll}1.0 & 1.4\end{array}\right] \pm 0.3}\end{array}$ & 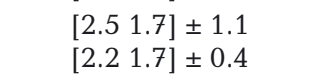 & $\begin{array}{l}0.71 \\
0.48\end{array}$ \\
\hline 062 & $\begin{array}{c}>2 \\
2-0.2\end{array}$ & $\begin{array}{l}0.013 \\
0.020\end{array}$ & $\begin{aligned} 0.84 & \pm 0.33 \\
1.5 & \pm 6.3\end{aligned}$ & $\begin{array}{r}209 \\
78\end{array}$ & $\begin{array}{c}0.17 \pm 0.02^{\mathrm{a}} \\
{[0.080 .12] \pm 0.16}\end{array}$ & $\begin{array}{c}0.90 \pm 0.20^{\mathrm{a}} \\
{\left[\begin{array}{ll}2.3 & 1.7\end{array}\right] \pm 3.5}\end{array}$ & $\begin{array}{l}0.53 \\
0.23\end{array}$ \\
\hline 065 & $\begin{array}{c}>2 \\
2-0.2\end{array}$ & $\begin{array}{l}0.005 \\
0.123\end{array}$ & $\begin{array}{c}46.8 \pm 10.4 \\
4.0 \pm 1.9\end{array}$ & $\begin{array}{l}233 \\
214\end{array}$ & $\begin{array}{c}{\left[\begin{array}{cc}11.7 & 10.9\end{array}\right] \pm 2.5} \\
{\left[\begin{array}{ll}0.6 & 0.9\end{array}\right] \pm 0.2}\end{array}$ & $\begin{array}{l}{\left[\begin{array}{ll}3.2 & 2.1\end{array}\right] \pm 0.5} \\
{\left[\begin{array}{ll}2.4 & 1.9\end{array}\right] \pm 0.6}\end{array}$ & $\begin{array}{l}0.83 \\
0.83\end{array}$ \\
\hline 066 & $\begin{array}{c}>2 \\
2-0.2\end{array}$ & $\begin{array}{l}0.035 \\
0.064\end{array}$ & $\begin{array}{l}57.7 \pm 37.9 \\
10.2 \pm 1.6\end{array}$ & $\begin{array}{r}71 \\
256\end{array}$ & $\begin{array}{l}{\left[\begin{array}{ll}4.4 & 4.1\end{array}\right] \pm 2.4} \\
{\left[\begin{array}{ll}1.9 & 2.6\end{array}\right] \pm 0.7}\end{array}$ & $\begin{array}{l}{\left[\begin{array}{ll}8.1 & 5.3\end{array}\right] \pm 3.3} \\
{\left[\begin{array}{ll}4.4 & 3.3\end{array}\right] \pm 0.7}\end{array}$ & $\begin{array}{l}0.83 \\
0.87\end{array}$ \\
\hline 068 & $\begin{array}{l}>20 \\
20-2 \\
2-0.2\end{array}$ & $\begin{array}{l}0.032 \\
0.004 \\
0.056\end{array}$ & $\begin{aligned} 2.5 & \pm 0.4 \\
73.1 & \pm 11.8 \\
8.5 & \pm 2.5\end{aligned}$ & $\begin{array}{l}170 \\
169 \\
156\end{array}$ & $\begin{array}{c}0.44 \pm 0.05^{\mathrm{a}} \\
{[13.212 .3] \pm 1.0} \\
{[0.91 .3] \pm 0.2}\end{array}$ & $\begin{array}{l}{\left[\begin{array}{ll}4.9 & 2.3\end{array}\right] \pm 0.3} \\
{\left[\begin{array}{ll}2.8 & 1.8\end{array}\right] \pm 0.2} \\
{\left[\begin{array}{ll}2.8 & 2.1\end{array}\right] \pm 0.4}\end{array}$ & $\begin{array}{l}0.90 \\
0.77 \\
0.84\end{array}$ \\
\hline
\end{tabular}


Table 4. Photosynthetic parameters estimated from $P-E$ curves of total particulate organic carbon (POC) based on joint fit of UV-opaque (UVO) and UVtransparent (UVT) curves from all stations. The UVT values for $P_{\mathrm{s}}^{\mathrm{B}}$ and $\beta$ reflect application of the corresponding UV treatment factor $\left(F_{\mathrm{a}}\right.$ and $F_{\mathrm{b}}$, respectively) for total POC (cf. Table 2). $\alpha \cdot 10^{3}$ : photosynthetic efficiency [mg C $\mathrm{mg} \mathrm{chl} \mathrm{a} \mathrm{a}^{-1} \mathrm{~h}^{-1}$ ( $\mathrm{mol}$ photon $\left.\mathrm{m}^{-2} \mathrm{~s}^{-1}\right)^{-1}$ ]; $E_{\mathrm{s}}$ : saturation irradiance ( $\mu \mathrm{mol}$ photon $\left.\mathrm{m}^{-2} \mathrm{~s}^{-1}\right) ; P_{\mathrm{s}}^{\mathrm{B}}$ : normalized maximum productivity (mg C $\mathrm{mg} \mathrm{chl} a^{-1} \mathrm{~h}^{-1}$ ); $\beta \cdot 10^{3}$ : photoinhibition coefficient [mg C mg chl a $\mathrm{m}^{-1} \mathrm{~h}^{-1}$ ( $\mathrm{mmol}$ photon $\left.\mathrm{m}^{-2} \mathrm{~s}^{-1}\right)^{-1}$ ]; $\mathrm{R}^{2}$ : squared correlation index (dimensionless)

\begin{tabular}{|c|c|c|c|c|c|}
\hline Stn & $\alpha \cdot 10^{3} \pm \mathrm{SE}$ & $E_{\mathrm{s}}$ & $P_{\mathrm{s}}^{\mathrm{B}}[\mathrm{UVT} \mathrm{UVO}] \pm \mathrm{SE}$ & $\beta \cdot 10^{3}[\mathrm{UVT} \mathrm{UVO}] \pm \mathrm{SE}$ & $\mathrm{R}^{2}$ \\
\hline 058 & $7.2 \pm 2.3$ & 229 & {$\left[\begin{array}{ll}1.5 & 1.6\end{array}\right] \pm 0.2$} & {$\left[\begin{array}{ll}1.7 & 0.9\end{array}\right] \pm 0.2$} & 0.78 \\
\hline 060 & $8.4 \pm 2.1$ & 202 & {$\left[\begin{array}{ll}1.5 & 1.7\end{array}\right] \pm 0.2$} & {$\left[\begin{array}{ll}2.5 & 1.3\end{array}\right] \pm 0.2$} & 0.90 \\
\hline 062 & $1.9 \pm 5.6$ & 113 & {$\left[\begin{array}{lll}0.20 & 0.22\end{array}\right] \pm 0.3$} & {$\left[\begin{array}{ll}2.5 & 1.3\end{array}\right] \pm 2.2$} & 0.70 \\
\hline 065 & $9.7 \pm 3.2$ & 191 & {$\left[\begin{array}{ll}1.7 & 1.9\end{array}\right] \pm 0.4$} & {$\left[\begin{array}{ll}4.3 & 2.3\end{array}\right] \pm 0.6$} & 0.83 \\
\hline 066 & $24.3 \pm 3.8$ & 120 & {$\left[\begin{array}{ll}2.6 & 2.9\end{array}\right] \pm 0.3$} & {$\left[\begin{array}{ll}5.2 & 2.8\end{array}\right] \pm 0.3$} & 0.86 \\
\hline 068 & $11.4 \pm 3.2$ & 149 & {$\left[\begin{array}{ll}1.5 & 1.7\end{array}\right] \pm 0.2$} & {$\left[\begin{array}{ll}3.4 & 1.8\end{array}\right] \pm 0.3$} & 0.88 \\
\hline
\end{tabular}

Unlike POC, DOC production did not follow the kinetics of the $P-E$ curves (Fig. 4). Values were quite noisy in some of the stations (Stns 060 and 066) and occasionally resulted in negative values when DOC production in the dark bottle was subtracted (Stn 065) (Fig. 4), maybe due to DOC consumption by bacteria (Morán \& Estrada 2002). These values are assumed to be zero in further numerical calculations. Moreover, there were clear differences in the pattern of DOC production between the 2 spectral treatments that resulted in significant quantitative and qualitative dif-
Fig. 4. Dissolved organic carbon (DOC) productivity values versus irradiance from all stations. Observed DOC values were fitted to a linear equation in the UV-opaque (UVO) treatment and to a second-degree polynomial curve in the UVtransparent (UVT) treatment. Open triangles and discontinuous lines correspond to observed and estimated values, respectively, of the UVO treatment. Solid dots and solid lines correspond to observed and estimated values, respectively, of the UVT treatment. In the lower and upper panels, $x$-axes represented photosynthetically active radiation (PAR) ( $\mu \mathrm{mol}$ photon $\mathrm{m}^{-2} \mathrm{~s}^{-1}$ ) and the equivalent PAR+UVR $\left(\mathrm{W} \mathrm{m}^{-2}\right)$, respectively, for each station. Note that irradiance scaling is different between stations to improve clarity. $P^{\mathrm{B}}$ : photosynthesis normalized to $\mathrm{chl} a$
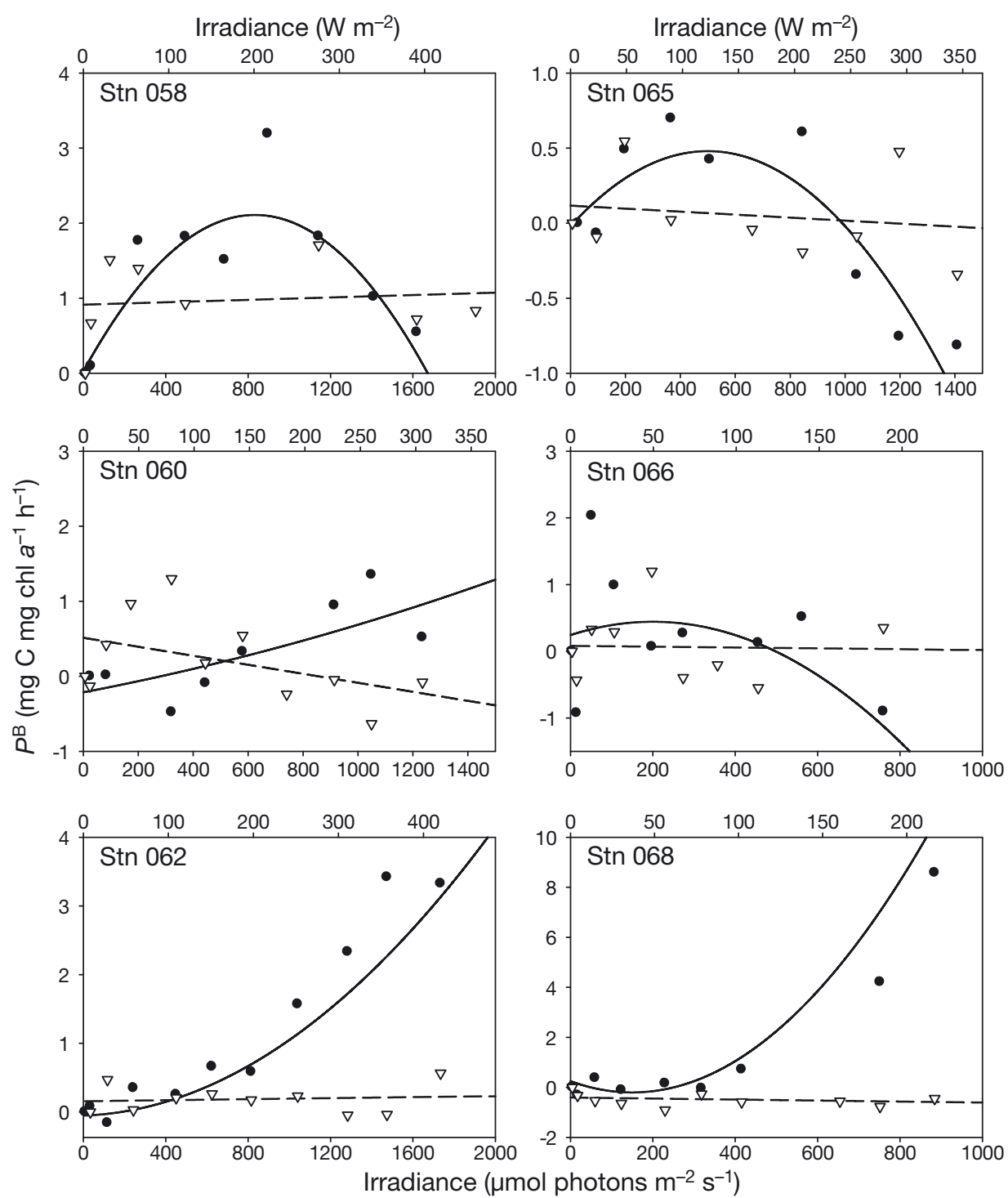


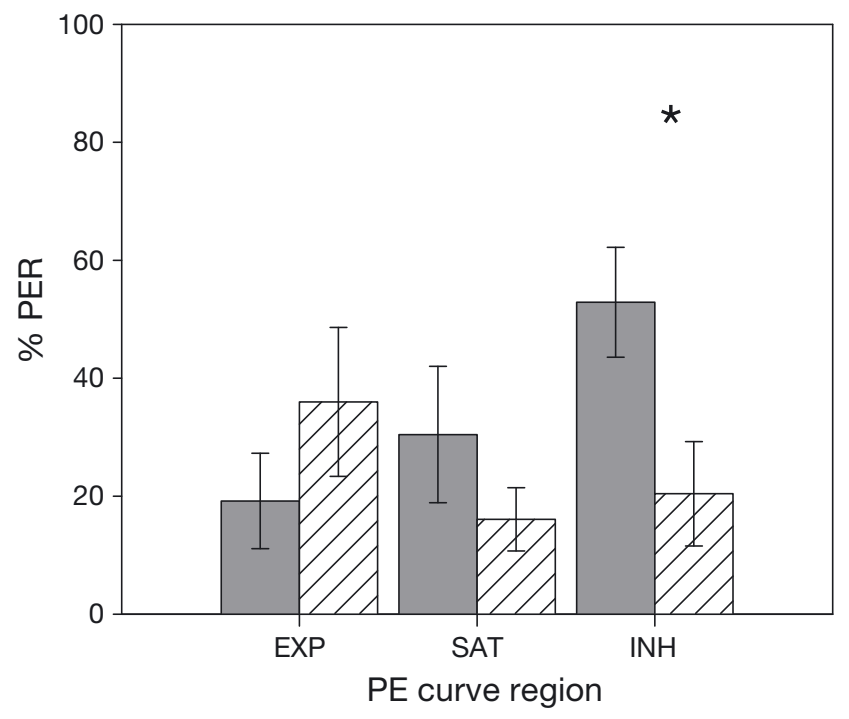

Fig. 5. Mean percentage of extracellular release (\% PER, $\pm \mathrm{SE}$ ) from all stations in the different $P-E$ curve regions. Grey bars correspond to the UV-transparent (UVT) treatment, and white bars correspond to the UV-opaque (UVO) treatment. Significant differences ( $t$-test) between treatments are shown by a black star. EXP: exponential phase under low irradiances; SAT: saturation phase under moderate irradiances; INH: photoinhibition phase under high irradiances

ferences (RMANOVA and Dunn's post test, $\mathrm{p}<0.05$, $\mathrm{n}=48$, Fig. 4). Mean value \pm SE of DOC under UVO yielded $0.29 \pm 0.06 \mathrm{mg} \mathrm{C} \mathrm{mg} \mathrm{chl} a^{-1} \mathrm{~h}^{-1}$, while DOC mean value under UVT was 3.03 times higher, corresponding to $0.87 \pm 0.20 \mathrm{mg} \mathrm{C} \mathrm{mg} \mathrm{chl} a^{-1} \mathrm{~h}^{-1}$. While DOC production under the UVO treatment was irradiance independent and nearly constant under a broad gradient of irradiance in all stations, DOC production under UVR exposures was irradiance dependent (Fig. 4). Under low irradiances, DOC was similar in both spectral treatments but increased exponentially with increasing irradiance. In some stations (i.e. Stns 058 and 065), DOC production decreased after reaching maximum values at intermediate irradiances to values similar to or lower than those observed under dark conditions. In others, mainly those with shallower mixed layers and sampling depths (i.e. Stns 062 and 068), DOC exponential trends continued until reaching maximum irradiance values, showing significantly higher productivity than in the other stations.

Consequently, with higher DOC concentrations under UVR exposures, the mean percentage of extracellular release, $\mathrm{PER}=\mathrm{DOC} /(\mathrm{POC}+\mathrm{DOC})$, was also higher in the UVT treatment than in the UVO treatment (RMANOVA and Dunn's post test, $\mathrm{p}>0.05, \mathrm{n}=$ 52). Average PER under PAR exposures (UVO treatment) was $21.96 \pm 3.71$ (mean $\pm \mathrm{SE}$ ), while it almost doubled $(42.54 \pm 4.80)$ under the full solar spectra (UVT treatment). A second analysis to compare PER responses under different photophysiological states of phytoplankton communities under the 2 different spectral treatments was also made. Irradiance was divided in 3 states or irradiance ranges: a light-limited range from dark conditions to the irradiance corresponding to the $E_{\mathrm{s}}$ value estimated from the $P-E$ curves (Table 4), a saturating range from the $E_{\mathrm{s}}$ to the photoinhibition threshold irradiance obtained directly from the $P-E$ curves (Fig. 3), and a photoinhibitory range from the photoinhibition threshold irradiance to the highest irradiance tested. Results showed that there were no differences between spectral treatments in the light-limited and saturating irradiance ranges ( $t$-test, $\mathrm{p}=0.173, \mathrm{n}=6$ and $t$-test, $\mathrm{p}=0.228$, $\mathrm{n}=6$, respectively), but a significant difference was found under photoinhibitory irradiances ( $t$-test, $\mathrm{p}=$ $0.019, \mathrm{n}=6$ ), showing PER under the UVT treatment with values 2.59 times higher $(52.88 \pm 9.30)$ than PER under the UVO treatment (20.41 \pm 8.85) (Fig. 5).

\section{DISCUSSION}

The experimental approach of this study used solar radiation to obtain realistic spectral treatments including UVR. The environmental conditions during and before the water sampling were different from those usually observed in most previous UVR studies, typically from coastal waters of temperate and polar latitudes where the changes in water transparency and mixing of the surface layer expose phytoplankton to a wide range of irradiance magnitude and spectral composition. Water transparency in the studied area was very high so that the depth of the photic layer averaged $137 \pm 13 \mathrm{~m}$ (mean $\pm \mathrm{SE}$ ) in the gyral stations and $113 \pm 5 \mathrm{~m}$ in the coastal stations. This, combined with the predominantly calm weather conditions and dominance of clear skies during most of the tested stations (Fig. 1), helped to assess UVR effects on phytoplankton assemblages grown in very clear water columns. High solar irradiance and stratification may induce the genetic and phenotypic adaptation of tropical phytoplankton communities to high PAR and UVR irradiance, with photoprotective strategies, photoacclimation and photoadaptation degrees developed to a maximum level. However, some of these taxa, such as Synechococcus, have been shown to be quite sensitive to UVR, even when grown under conditions typical of tropical surface layers (Neale et al. 2014). Despite a possible genetic adaptation, the results from this study demonstrate 
that solar UVR acts as an important environmental factor in the oligotrophic areas of the Indian Ocean, significantly affecting the phytoplanktonic production of both POC and DOC.

To find the best model to fit the carbon fixation values obtained from the solar incubations, several photoinhibitory models were initially tested (data not shown) (Platt et al. 1980, Cullen et al. 1992, Sobrino et al. 2005a). The model proposed by Cullen et al. (1992) was discarded because it needs a high number of measurements under low irradiances to perform a good fit. This was impossible to achieve in our experiment due to the space limitation inside the incubator that made us give preference to high rather than to low light treatments. For similar reasons, we gave preference to the number of experimental treatments (11 irradiance levels) rather than to the replicates per experimental treatment, which would result in very poor fitting of the models. In the model from Platt et al. (1980), a modification including the hyperbolic tangent function was done. This modification was proposed by Jassby \& Platt (1976) as the best function to describe phytoplankton natural communities, and it fitted better to the observed data. However, in their model $P_{\mathrm{s}}^{\mathrm{B}}$, the maximum photosynthetic production in the absence of inhibition has a strong interdependency on $\beta$, such that when there are few observations, neither parameter is well constrained. In contrast, in the T model from Sobrino et al. (2005a), the photoinhibitory parameter $\beta$ is decoupled from the other photosynthetic parameters. Both the Platt et al. (1980) and the Sobrino et al. (2005a) models showed fits with similar quality in trial fits to individual incubation results $\left(\mathrm{r}^{2}=0.84 \pm 0.10\right.$ and $\mathrm{r}^{2}=0.83 \pm 0.08$, respectively $[\mathrm{n}=34])$. However, the 2 other parameters, $\alpha$ and $P_{\mathrm{s}}^{\mathrm{B}}$, remain interdependent, i.e. in the presence of few points, similar fits are obtained from a high $\alpha$ and low $P_{\mathrm{s}}^{\mathrm{B}}$ as from a low $\alpha$ and high $P_{\mathrm{s}}{ }^{\mathrm{B}}$. Thus, in the initial fits, we focused on the realized maximum rate of photosynthesis in the presence of inhibition, $P_{\mathrm{m}}^{\mathrm{B}}$, instead of $P_{\mathrm{s}}^{\mathrm{B}}$. From these fits, it was verified that photosynthesis in the UVT and UVO treatments was similar at low irradiance but was lower in the UVT treatment than in the UVO treatment at high irradiance. Based on this observation, we pooled UVO and UVT data to better constrain $P_{\mathrm{s}}{ }^{\mathrm{B}}$ in a joint fit, introducing factors $F_{\mathrm{a}}$ and $F_{\mathrm{b}}$ for the UV effect on $P_{\mathrm{s}}^{\mathrm{B}}$ and $\beta$.

For total POC, the estimates of factors $F_{\mathrm{a}}$ and $F_{\mathrm{b}}$ for the UV effect on $P_{\mathrm{s}}^{\mathrm{B}}$ and $\beta$ were consistent with the assumptions of the T model: UV exposure had minor effects on $P_{\mathrm{s}}^{\mathrm{B}}$ but a large effect on $\beta$. In our fits of the $\mathrm{T}$ model using PAR as the irradiance variable, $\beta$ rep- resents the overall inhibition weight for solar irradiance per unit PAR, which will be higher in the presence of UV. However, in the smaller fraction $(0.2$ to $2 \mu \mathrm{m})$, the presence of UV resulted in both a decrease in $P_{\mathrm{s}}^{\mathrm{B}}$ and an increase in $\beta$. These results are consistent with recent studies of the photosynthetic response to UV in picophytoplankton, in which it was observed that the $\mathrm{T}$ model tended to underestimate the actual $P_{\mathrm{s}}^{\mathrm{B}}$ because it did not account for the significant inhibition that occurred even at moderate exposures (i.e. less than the threshold) (Neale et al. 2014). Another model ( $\left.E_{\max }\right)$ was proposed that accounted for inhibition at moderate exposures.

The results also showed that phytoplankton in the 3 gyral stations showed lower sensitivity to photoinhibition (as expressed by $\beta$, Tables $3 \& 4$ ) than phytoplankton in the stations closest to the coast ( $p=$ 0.016 if Stn 062 is omitted). This finding may be related to factors such as a stronger photoacclimation of phytoplankton in the gyral stations, which on average had more transparent waters and had been exposed to higher solar irradiances (Table 1) than the coastal stations. In fact, comparison of $\beta$ among stations and spectral treatments indicates that, reinforcing the latter contention, acclimation to high light happened for both UVR and PAR, and no significant differences were found when comparing UVT:UVO ratios of $P_{\mathrm{m}}^{\mathrm{B}}$ and $\beta$ within each group of stations. Thus, a good fit to both total and fractionated POC data was obtained by using the overall UVT treatment factors $F_{\mathrm{a}}$ and $F_{\mathrm{b}}$. Nevertheless, despite the high acclimation of tropical phytoplankton, high solar irradiances for both PAR and UVR exposures produced photoinhibition in the studied samples in all of the stations. UVR exerted a $10 \%$ decrease in maximum photosynthetic rates and an $86 \%$ higher sensitivity to UVR measured as $\beta$ for total POC incorporation compared to samples where UVR was excluded. These values might overestimate the inhibition of in situ rates and sensitivity at the sampling depth since the UVR:PAR ratio at the surface during the incubations were higher than the ratio at the $20 \%$ PAR depth. UV-B also had more weight at the surface than at the sampling depth where UV-A was the major component of the UVR. Although reports describing the degree of primary production photoinhibition under natural UVR in oligotrophic oceans are scarce, Li et al. (2011) and Conan et al. (2008) showed a 27 to $55 \%$ inhibition of primary production by UV in surface tropical offshore waters, comparable with the $49 \%$ inhibition at the highest irradiances in our study (Fig. 3). For comparison, natural Antarctic phytoplankton assemblages exposed to solar radi- 
ation suffered between 34 and $44 \%$ photoinhibition (Boucher \& Prézelin 1996, Holm-Hansen 1997). Regarding photoinhibition on different phytoplankton cell sizes, although the nanoplanktonic fraction, with cells larger than $2 \mu \mathrm{m}$, was almost 3 times more productive than the picoplanktonic fraction $(0.2$ to $2 \mu \mathrm{m})$, sensitivity of photoinhibition to both UVR and PAR (as indicated by $\beta$ ) was not related to cell size. The results agree with those from Laurion \& Vincent (1998), which demonstrated that cellular size is not a good index for UV radiation sensitivity of phytoplankton assemblages from large and oligotrophic Arctic lakes. The picoplanktonic fraction, however, did exhibit significant UV inhibition even in the PAR saturation range (similar to the $E_{\max }$ model, see above), suggesting a lower capacity for repair compared to the larger size fraction.

In contrast to POC, phytoplanktonic DOC production was significantly higher under exposures including UVR and did not follow the typical photosynthesis-irradiance pattern. Although nowadays it is well established that the extracellular release of recently photosynthesized products is a normal feature from healthy cells (Mague et al. 1980) and can be predicted from POC values (Marañón et al. 2005), our results demonstrate that its magnitude can suffer variations with increasing UVR irradiance. In contrast, PAR-exposed samples did not show significant differences in DOC from dark conditions up to $1900 \mu \mathrm{mol}$ photons $\mathrm{m}^{-2} \mathrm{~s}^{-1}$ (Fig. 4). The latter results agree with those from Marañón et al. (2005), who demonstrated that DOC produced by phytoplankton from oligotrophic waters in the Celtic Sea did not vary significantly over a broad range of PAR irradiance. Under UVR, DOC production increased exponentially as much as 3 times compared to conditions without UVR and more under high and photoinhibitory exposures than under low or saturating irradiances for POC production, which indicates that DOC release can be mainly considered a response to stress. In fact, at Stns 058, 065 and 066, DOC production decreased and approached zero at very high irradiances, probably due to UVR damage. Although this study lacks detailed information about mixing regimes and turbulence from the sampled stations, it seems clear that DOC production is also related to the acclimation degree, which depends simultaneously on factors such as the depth of the mixed layer and the history of solar irradiance. For example, Stns 062 and 068, which showed an exponential increase in DOC without further inhibition, were the stations with the shallowest mixed layers. In contrast, Stns 065 and 066, which showed inhibition of DOC under high irradiance levels, had some of the deepest mixed layers and were also some of the most photoinhibited stations (Table 3). Authors such as Fogg (1983), Wood \& Van Valen (1990) or Berman-Frank \& Dubinsky (1999) proposed that DOC production represents an adaptive process by which phytoplankton communities try to mitigate the harmful effects produced by adverse conditions such as high irradiances and low nutrient concentrations. Following with this contention, DOC production would be related to an uncoupling between the quantity of absorbed energy by the cells and its assimilation as processed material. However, it is not clear yet if this is a passive response (i.e. release) or an active mechanism (i.e. excretion) that could, for example, work as a dissipative pump of potentially damaging metabolites as proposed for other physiological mechanisms such as the nitrite pump (Guerrero \& Jones 1996, Lomas \& Lipschultz 2006). It could be possible that cells acclimated and genetically adapted to live under high light solar exposures in waters with high UV levels, water transparency and low nutrient concentrations were able to use DOC production as a physiological mechanism to avoid further cell damage. For passive release, increases in membrane permeability or in cell lysis could also contribute to elevated DOC levels. Recent results have demonstrated higher cell lysis rates in oligotrophic waters than in more productive areas, showing a direct relationship between phytoplankton cell lysis rates and DOC production (Agustí \& Duarte 2013). Increases in cell permeability and cell mortality by UVR have also been reported (Sobrino et al. 2004, Llabrés \& Agustí 2006, Llabrés et al. 2010). UVR could also be exerting damage to some steps of the carbon fixation cycle, affecting the conversion of complex POC molecules, increasing the excitation pressure inside the cell and releasing DOC as one of the earliest metabolites of the cycle. As a general view combining conclusions from this and the referred scientific reports, it is possible to infer that below a threshold in irradiance, UVR does not provoke enough stress to release significantly higher DOC than under non-photoinhibitory PAR exposures. Once the threshold is exceeded, DOC production increases with irradiance to release excess energy. At very high irradiances, UVR damage exceeds repair rates, and cells that are not able to cope with the highly stressing conditions interrupt cell metabolism and consequently stop DOC production. Similar to this response, Neale et al. (2014) show that the repair rate of Synechococcus increases gradually with irradiance until reaching a maximum in irradiance. Above this maximum, the damage due to 
high irradiances cannot be counteracted by the constant repair rate and negative effects accumulate, leading to the breakdown of cellular metabolism.

Although no studies have directly assessed UVR effects on phytoplanktonic DOC concentrations from oligotrophic marine waters, similar results were observed for phytoplankton from alpine lakes with similar characteristics of low nutrient loadings, high transparency and high UVR levels (Carrillo et al. 2002, Panzenböck 2007). Phytoplanktonic DOC production has also usually been found to be higher in oligotrophic areas and alpine lakes than in coastal waters of temperate areas or opaque lakes (Teira et al. 2001, Morán et al. 2002, López-Sandoval et al. 2011, Helbling et al. 2013), where the microbial trophic webs driven by regenerated production dominate in comparison with the autotrophic communities based on herbivorous trophic webs. Furthermore, results comparing 30 lakes with different physicochemical characteristics demonstrated that pre-exposure of dissolved organic matter to UVR increased bacterial growth only in oligotrophic lakes (Tranvik \& Bertilsson 2001). All of these links between such distant ecosystems evidences the important role of UVR from an evolutionary perspective for the biological processes taking place in these waters. Further knowledge about the physiological role, magnitude and fate of phytoplanktonic DOC production under the whole solar spectrum including UVR and its role on the carbon cycle and on the microbial trophic web in oligotrophic marine areas is still necessary to achieve a better understanding of these important open-ocean ecosystems (del Giorgio \& Duarte 2002).

Acknowledgements. This study was possible thanks to the project Malaspina 2010 from the Spanish Ministry of Innovation and Science (MICINN, Consolider 2008-00077), the crew of the RV 'Hespérides' and staff of the Marine Technological Unit (UTM). Thanks also to Maximino Delgado, who examined the phytoplankton samples, and to Silvia.

\section{LITERATURE CITED}

Agustí S, Duarte CM (2013) Phytoplankton lysis predicts dissolved organic carbon release in marine plankton communities. Biogeosciences 10:1259-1264

> Berman-Frank I, Dubinsky Z (1999) Balanced growth in aquatic plants: myth or reality? Bioscience 49:29-37

Boucher NP, Prézelin BB (1996) An in situ biological weighting function for UV inhibition of phytoplankton carbon fixation in the Southern Ocean. Mar Ecol Prog Ser 144: 223-236

Buma AGJ, VanHannen EJ, Veldhuis MJW, Gieskes WWC (1996) UV-B induces DNA damage and DNA synthesis delay in the marine diatom Cyclotella sp. Sci Mar 60: 101-106
Buma AGJ, Boelen P, Jeffrey WH (2003) UVR-induced DNA damage in aquatic organisms. In: Helbling EW, Zagarese $\mathrm{H}$ (eds) UV effects in aquatic organisms and ecosystems. Comprehensive series in photochemistry and photobiology, Vol 1. Royal Society of Chemistry, Cambridge, p 291-328

Buma AGJ, Wright SW, van den Enden R, van de Poll WH, Davidson AT (2006) PAR acclimation and UVBR-induced DNA damage in Antarctic marine microalgae. Mar Ecol Prog Ser 315:33-42

Capotondi A, Alexander MA, Bond NA, Curchitser EN, Scott JD (2012) Enhanced upper-ocean stratification with climate change in the CMIP3 models. J Geophys Res Oceans 117:C04031, doi:10.1029/2011JC007409

Carmack EC, Macdonald RW, Jasper S (2004) Phytoplankton productivity on the Canadian Shelf of the Beaufort Sea. Mar Ecol Prog Ser 277:37-50

Carrillo P, Medina-Sánchez JM, Villar-Argaiz M (2002) The interaction of phytoplankton and bacteria in a high mountain lake: importance of the spectral composition of solar radiation. Limnol Oceanogr 47:1294-1306

Conan P, Joux F, Torréton JP, Pujo-Pay M, Douki T, Rochelle-Newall E, Mari X (2008) Effect of solar ultraviolet radiation on bacterio- and phytoplankton activity in a large coral reef lagoon (southwest New Caledonia). Aquat Microb Ecol 52:83-98

Cullen JJ, Neale PJ, Lesser MP (1992) Biological weighting function for the inhibition of phytoplankton photosynthesis by ultraviolet radiation. Science 258:646-650

del Giorgio PA, Duarte CM (2002) Respiration in the open ocean. Nature 420:379-384

Estrada M (2012) Determinación fluorométrica de la concentración de clorofila a. In: Moreno-Ostos E (ed) Expedición de circunnavegación Malaspina 2010. Cambio global y exploración de la biodiversidad del océano. Libro blanco de métodos y técnicas de trabajo oceanográfico. Consejo Superior de Investigaciones Científicas, Madrid, p 399-405

Field CB, Behrenfeld MJ, Randerson JT, Falkowski P (1998) Primary production of the biosphere: integrating terrestrial and oceanic components. Science 281: 237-240

Fogg GE (1983) The ecological significance of extracellular products of phytoplankton photosynthesis. Bot Mar 26: 3-14

> Forget MH, Sathyendranath S, Platt $\mathrm{T}$, Pommier J, Vis C, Kyewalyanga MS, Hudon C (2007) Extraction of photosynthesis-irradiance parameters from phytoplankton production data: demonstration in various aquatic systems. J Plankton Res 29:249-262

> Frouin R, Pinker RT (1995) Estimating photosynthetically active radiation (PAR) at the earth's surface from satellite observations. Remote Sens Environ 51:98-107

Gao K, Wu Y, Li G, Wu H, Villafañe VE, Helbling EW (2007a) Solar UV radiation drives $\mathrm{CO}_{2}$ fixation in marine phytoplankton: a double-edged sword. Plant Physiol 144: 54-59

> Gao K, Li G, Helbling EW, Villafañe VE (2007b) Variability of UVR effects on photosynthesis of summer phytoplankton assemblages from a tropical coastal area of the South China Sea. Photochem Photobiol 83:802-809

Garcia-Pichel F (1994) A model for internal self-shading in planktonic organisms and its implications for the usefulness of ultraviolet sunscreens. Limnol Oceanogr 39: 1704-1717 
Guerrero MA, Jones RD (1996) Photoinhibition of marine nitrifying bacteria. II. Dark recovery after monochromatic or polychromatic irradiation. Mar Ecol Prog Ser 141:193-198

Häder DP, Helbling EW, Williamson CE, Worrest RC (2011) Effects of UV radiation on aquatic ecosystems and interactions with climate change. Photochem Photobiol Sci 10:242-260

- Helbling EW, Villafañe V, Ferrario M, Holm-Hansen O (1992) Impact of natural ultraviolet radiation on rates of photosynthesis and on specific marine phytoplankton species. Mar Ecol Prog Ser 80:89-100

> Helbling EW, Buma AGJ, De Boer MK, Villafañe VE (2001) In situ impact of solar ultraviolet radiation on photosynthesis and DNA in temperate marine phytoplankton. Mar Ecol Prog Ser 211:43-49

- Helbling EW, Gao K, Gonçalves RJ, Wu H, Villafañe VE (2003) Utilization of solar UV radiation by coastal phytoplankton assemblages off SE China when exposed to fast mixing. Mar Ecol Prog Ser 259:59-66

> Helbling EW, Carrillo P, Medina-Sánchez JM, Durán C, Herrera G, Villar-Argaiz M, Villafañe VE (2013) Interactive effects of vertical mixing, nutrients and ultraviolet radiation: in situ photosynthetic responses of phytoplankton from high mountain lakes in Southern Europe. Biogeosciences 10:1037-1050

Henderson GS, McConnell JC, Beagley SR, Evans WFJ (1991) Polar ozone depletion: current status. Can J Phys 69: 1110-1122

Herbland A, Voituriez B (1979) Hydrological structure analysis for estimating the primary production in the tropical Atlantic Ocean. J Mar Res 37:87-101

> Holm-Hansen O (1997) Short- and long-term effects of UVA and UVB on marine phytoplankton productivity. Photochem Photobiol 65:266-268

Jassby AD, Platt T (1976) Mathematical formulation of relationship between photosynthesis and light for phytoplankton. Limnol Oceanogr 21:540-547

Key RM, Kozyr A, Sabine CL, Lee K and others (2004) A global ocean carbon climatology: results from global data analysis project (GLODAP). Global Biogeochem Cycles 18:GB4031, doi:10.1029/2004GB002247

Kirk JTO (1983) Light and photosynthesis in aquatic organisms. Cambridge University Press, Cambridge

Laurion I, Vincent WF (1998) Cell size versus taxonomic composition as determinants of UV-sensitivity in natural phytoplankton communities. Limnol Oceanogr 43: 1774-1779

Li G, Wu YP, Gao KS (2009) Effects of Typhoon Kaemi on coastal phytoplankton assemblages in the South China Sea, with special reference to the effects of solar UV radiation. J Geophys Res Biogeosci 114:9

Li G, Gao K, Gao G (2011) Differential impacts of solar UV radiation on photosynthetic carbon fixation from the coastal to offshore surface waters in the South China Sea. Photochem Photobiol 87:329-334

> Llabrés M, Agustí S (2006) Picophytoplankton cell death induced by UV radiation: evidence for oceanic Atlantic communities. Limnol Oceanogr 51:21-29

Llabrés M, Agustí S, Alonso-Laita P, Herndl GJ (2010) Synechococcus and Prochlorococcus cell death induced by UV radiation and the penetration of lethal UVR in the Mediterranean Sea. Mar Ecol Prog Ser 399:27-37

> Lomas MW, Lipschultz F (2006) Forming the primary nitrite maximum: nitrifiers or phytoplankton? Limnol Oceanogr 51:2453-2467
López-Sandoval DC, Fernández A, Maranón E (2011) Dissolved and particulate primary production along a longitudinal gradient in the Mediterranean Sea. Biogeosciences 8:815-825

Lubián LM (2012) Determinación de la abundancia de nano y picofitoplancton mediante citometría de flujo. In: Moreno-Ostos E (ed) Expedición de circunnavegación Malaspina 2010. Cambio global y exploración de la biodiversidad del océano. Libro blanco de métodos y técnicas de trabajo oceanográfico. Consejo Superior de Investigaciones Científicas, Madrid, p 381-385

> Mague TH, Friberg E, Hughes DJ, Morris I (1980) Extracellular release of carbon by marine-phytoplankton; a physiological approach. Limnol Oceanogr 25:262-279

> Marañón E, Cermeño P, Pérez V (2005) Continuity in the photosynthetic production of dissolved organic carbon from eutrophic to oligotrophic waters. Mar Ecol Prog Ser 299:7-17

Mitchell DL, Karentz D (1993) The induction and repair of DNA photodamage in the environment. In: Young AR, Moan J, Björn LO, Nultsch W (eds) Environmental UV photobiology. Plenum Press, New York, NY, p 345-377

> Molina MJ, Rowland FS (1974) Stratospheric sink for chlorofluoromethanes: chlorine atom-catalysed destruction of ozone. Nature 249:810-812

Moran MA, Zepp RG (1997) Role of photoreactions in the formation of biologically labile compounds from dissolved organic matter. Limnol Oceanogr 42:1307-1316

Morán XAG, Estrada M (2002) Phytoplanktonic DOC and POC production in the Bransfield and Gerlache Straits as derived from kinetic experiments of ${ }^{14} \mathrm{C}$ incorporation. Deep-Sea Res II 49:769-786

> Morán XAG, Estrada M, Gasol JM, Pedrós-Alió C (2002) Dissolved primary production and the strength of phytoplankton-bacterioplankton coupling in contrasting marine regions. Microb Ecol 44:217-223

> Neale PJ (2001) Modeling the effects of ultraviolet radiation on estuarine phytoplankton production: impact of variations in exposure and sensitivity to inhibition. J Photochem Photobiol B 62:1-8

- Neale PJ, Pritchard AL, Ihnacik R (2014) UV effects on the primary productivity of picophytoplankton: biological weighting functions and exposure response curves of Synechococcus. Biogeosciences 11:2883-2895

> Panzenböck M (2007) Effect of solar radiation on photosynthetic extracellular carbon release and its microbial utilization in alpine and Arctic lakes. Aquat Microb Ecol 48:155-168

Platt T, Gallegos CL, Harrison WG (1980) Photoinhibition of photosynthesis in natural assemblages of marine phytoplankton. J Mar Res 38:687-701

Rao RR, Molinari RL, Festa JF (1989) Evolution of the climatological near surface thermal structure of the tropical Indian Ocean: 1. Description of mean monthly mixed layer depth, and sea surface temperature, surface current, and surface meteorological fields. J Geophys Res 94: 10801-10815

Ravishankara A (2009) Findings from the 2006 ozone scientific assessment for the Montreal protocol. Springer, New York, NY

> Schofield O, Kroon BMA, Prézelin BB (1995) Impact of ultraviolet-B radiation on photosystem-II activity and its relationship to the inhibition of carbon fixation rates for antarctic ice algae communities. J Phycol 31: $703-715$ 
Sharp JH (1977) Excretion of organic matter by marine phytoplankton: Do healthy cells do it? Limnol Oceanogr 22:381-399

Sobrino C, Montero O, Lubian LM (2004) UV-B radiation increases cell permeability and damages nitrogen incorporation mechanisms in Nannochloropsis gaditana. Aquat Sci 66:421-429

Sobrino C, Neale PJ, Lubian LM (2005a) Interaction of UV radiation and inorganic carbon supply in the inhibition of photosynthesis: spectral and temporal responses of two marine picoplankton. Photochem Photobiol 81:384-393

Sobrino C, Neale PJ, Montero O, Lubian LM (2005b) Biological weighting function for xanthophyll de-epoxidation induced by ultraviolet radiation. Physiol Plant 125:41-51

Steeman-Nielsen E (1952) The use of radioactive carbon (C14) for measuring organic production in the sea. J Cons Int Explor Mer 18:117-140

Strom SL, Benner R, Ziegler S, Dagg MJ (1997) Planktonic grazers are a potentially important source of marine dissolved organic carbon. Limnol Oceanogr 42:1364-1374

Teira E, Pazó MJ, Serret P, Fernández E (2001) Dissolved organic carbon production by microbial populations in the Atlantic Ocean. Limnol Oceanogr 46:1370-1377

Tranvik LJ, Bertilsson S (2001) Contrasting effects of solar

Editorial responsibility: Just Cebrian,

Dauphin Island, Alabama, USA
UV radiation on dissolved organic sources for bacterial growth. Ecol Lett 4:458-463

UNEP (United Nations Environment Programme) (2000) The Montreal protocol on substances that deplete the ozone layer as either adjusted and/or amended in London 1990, Copenhagen 1992, Vienna 1995, Montreal 1997, Beijing 1999. United Nations Environment Programme, Nairobi

Villafañe VE, Buma AGJ, Boelen P, Helbling EW (2004) Solar UVR-induced DNA damage and inhibition of photosynthesis in phytoplankton from Andean lakes of Argentina. Arch Hydrobiol 161:245-266

Vincent WF, Neale PJ (2000) Mechanisms of UV damage to aquatic organisms. In: de Mora SJ, Demers S, Vernet M (eds) The effects of UV radiation on marine ecosystems. Cambridge University Press, Cambridge, p 149-176

Weatherhead EC, Andersen SB (2006) The search for signs of recovery of the ozone layer. Nature 441:39-45

Wetzel RG, Hatcher PG, Bianchi TS (1995) Natural photolysis by ultraviolet irradiance of recalcitrant dissolved organic matter to simple substrates for rapid bacterial metabolism. Limnol Oceanogr 40:1369-1380

Wood AM, Van Valen LM (1990) Paradox lost? On the release of energy-rich compounds by phytoplankton. Mar Microb Food Webs 4:103-116

Submitted: September 18, 2014; Accepted: July 8, 2015 Proofs received from author(s): August 31, 2015 